\title{
"Natural Born Sportsmen". Processes of Othering and Self-Charismatization of African Professional Footballers in Germany
}

\author{
Christian Ungruhe \\ Research Assistant, Chair of Social Anthropology, University of Bayreuth, \\ Universitätsstraße 30, 95440 Bayreuth, Germany \\ Email: christian.ungruhe@gmx.net
}

\begin{abstract}
At first sight, the perception of African footballers in Germany seems to be two-fold. Whereas amateur players may face racist assaults during matches time and again, open racism in professional German football has declined. Indeed, African players in the Bundesliga are frequently celebrated by fans and are icons of their clubs. However, this paper argues that the cheering of star players and forms of open racism during amateur matches are often only two extremes of a continuum since professional African footballers continue to be socially constructed as being different. Ascriptions of playing styles as elegant, powerful, and playful reflect alleged natural differences and manifest the otherness of African players. The article analyzes the historical construction of this manifestation and also discusses to what extent ascribed otherness is adopted by African footballers as a kind of "self-charismatization."
\end{abstract}

Keywords

football, stereotypes, othering, racism, migration

\section{Résumé}

A première vue, la perception des footballeurs africains d'Allemagne serait double : si les joueurs amateurs se trouvent toujours confrontés au cours des matches à des attaques racistes, le football professionnel d'outre-rhin aurait vu les manifestations de racisme le plus brutal fortement diminuer. En effet, des joueurs africains de la Bundesliga sont fréquemment célébrés par les fans et constituent de véritables icônes au sein de leur club. Toutefois, cet article entend démontrer que la manifestation de soutien à l'égard des joueurs vedettes et les formes les plus primaires de racisme au cours des matchs amateurs sont souvent les deux faces d'une même pièce puisque les footballeurs professionnels africains continuent d'être socialement perçus comme différents. Les styles de jeu décrits comme 'élégants', 'puissants' ou encore 'ludiques' sous-tendent l'idée qu'il existerait une différence naturelle et une altérité propres aux joueurs africains. Cet article entend analyser la construction historique de ce phénomène tout en se demandant dans 
quelle mesure les joueurs de foot africains n'auraient pas intégré cette altérité comme une forme 'd'autocharisme'.

Mots clés

football, stéréotypes, ostracisme, racisme, immigration

\section{Introduction}

Although African football migration to Europe is not a new phenomenon, its relevance for clubs, fans and the media has gained momentum in recent years (Lanfranchi and Taylor 2001: 167-89; Poli 2006; Darby 2010). As a result of the easing of foreign player restrictions in European football the number of African players ${ }^{1}$ in German leagues has increased significantly since the mid-199os. Following in the footsteps of a few pioneers during the 196os, 7os, and 8os the current generation of African footballers in Germany plays at various levels, from the professional Bundesliga to local amateur divisions. Players who succeed in entering European professional football quite often become celebrated stars and advertisements for their clubs (Künzler and Poli 2012). The case of the Ghanaian-born German international Gerald Asamoah who was regularly celebrated by the opponent fans when playing for his club FC Schalke 04 against FC St. Pauli and of the Ghanaian international Hans Sarpei who became a Facebook and twitter celebrity in Germany when he started to comment ironically on current issues in football may be extraordinary examples. However, they show the distinguished position of players of African origin in Germany (Fritsch 2013; Bardow 2013). In addition, whereas hostility towards African players in amateur leagues is an almost weekly phenomenon, open racism on the professional level has been declining in recent years (Glindmeier and Todt 2006; Pilz 2009).

One of the aims of this article is to show that in Germany recognized or even celebrated African footballers continue to be represented as different. Why is this a problem? It is then a problem when this difference grounds in alleged biological features that reproduce racial classifications. Since physical ability and a (more or less) direct bodily interaction between players on

\footnotetext{
1) African players is not a precise category and its boundaries may shift from context to context. Since this paper mainly deals with the processes of othering which relate to skin color as a distinctive feature, the term African players includes those black footballers who are portrayed as being African in the media and see themselves as African players regardless of their actual citizenship or place of origin.
} 
the field are essential qualities of sporting performance, representations in sports get their legitimation from physical features, especially in a team game like football. Focusing on the body as the apparently natural (even if trained) incorporation of sporting ability fits popular conceptions of a physical ethnic or national identity based on racial characteristics. Thereby, the representation of professional African footballers may ground in a colonial rhetoric of an evolutionary worldview.

The article will also discuss to what extent ascribed otherness is adopted by African football players as a kind of "self-charismatization" (Soeffner 1997: 65-7 and 81-2), not least in order to fulfill expected role models and exploit the advantages of possessing unique qualities. In this respect, self-charismatization may be conceptualized as a form of ethnic capital or strategic essentialism. However, as the analysis will show, acquiring sportive (and social) advantages by fulfilling role models is neither a passive asset nor strategic choice. Instead, self-charismatization refers, in this context, to an active and continuous yet rather implicit endeavor of the individual player to style himself with qualities in order to receive recognition.

By elaborating on the mechanisms and constructions of the representation of African players, the analysis shows that both the celebration of African players and their self-charismatization reproduce colonial images and thereby reproduce notions of racism. This continuous process of reproducing difference feeds the social knowledge about Africa in Germany and thus contributes to a representation of difference that may lead to a general manifestation of the African other. ${ }^{2}$ In order to be able to interpret the othering of African footballers, I will first present a historical review of the connection between football in Africa and the construction of otherness, followed by an outline of the history of African footballers in German (professional) football. Subsequently, I will outline the development of the image of African footballers in Germany from the time of the first African football migrants at the beginning of the 196os. This part leads to the empirical analyses of the appreciation, discrimination, and self-charismatization of African players in German professional football before summarizing the findings in the conclusion. ${ }^{3}$

2) If it is not clear from the context, problematic terms which may discredit a certain group of people or seem to overgeneralize and simplify specific practices and attitudes are marked in italics. These terms (e.g. African other, African mentality, integration) do not reflect the author's view but refer to discourses in the field of football, the media, or the public and are therefore needed to address the problem of the construction of otherness in this article.

3) The analysis draws on biographical interviews which were carried out with 40 current and former African professional players in Ghana and Germany. In addition, ten semi-structured 


\section{Football in Africa and the Construction of the Other}

In the mid-19th century, European settlers, soldiers, and sailors introduced football to Africa, first in South Africa and subsequently in other parts of the continent, spreading from coastal areas to the hinterland. Since then, the appropriation of the game has been an ambivalent and contested affair. On the one hand, from the 1920 s onwards, football was increasingly used by colonial administrators and Christian missionaries as a means of disciplining the local male population. ${ }^{4}$ This was both on the basis of "moralizing [the] leisure time" of young African men, as Tim Couzens (1982) has shown for South Africa and part of the curriculum in schools and other educational establishments, where football was used as a way to instill qualities such as self-control, team spirit, and submissiveness to the colonial authorities. It was a way of disciplining what was generally regarded as the foolish and lazy (but also powerful, and therefore threatening) negro (Alegi 2010: 1-13; Wachter 2006: 279-85).

On the other hand, football (and other sport) was appropriated by the local population (Alegi 2010: 14-35; Baller and Cornelissen 2011: 2090). Football was mainly played according to the English style of kick and rush, however, "supporters truly appreciated individual skills such as strength, improvisation and dribbling" (Pannenborg 2012: 29). Furthermore, playing football was a means for young African men to gain prestige and to negotiate social status, as Laura Fair (1997) has illustrated for colonial Zanzibar. Eventually, football played an important role in the growing struggle for independence in many African colonies (and against segregation in South Africa) in the period around the Second World War. While South African players developed a style based on feints and dribbling that symbolized a creative resistance against segregation and repression for the local population (Alegi 2002: 36 ), the emergent pan-African movement in other African countries appropriated the game as a means of

interviews were conducted with current coaches, functionaries, and agents. In order to cover a wide range of experiences of African footballers across several levels and times, senior players were selected according to various statuses (from 1 . Bundesliga to $5^{\text {th }}$ division [Oberliga]) and time spans of active playing. Interviews with current football players and with the director, the executive director, and the scouting head of three football academies in Ghana have been anonymized. Original German quotations have been translated into English by the author. I would like to thank the Bavarian State Ministry of Sciences, Research and the Arts for financing this research as well as a number of colleagues for their comments on this paper.

4) At that time, while British colonial administrations on the continent started to endorse football as a means to control the local population, French authorities "feared the political and organizational potential" as a means for resistance and hesitated to support the game. Therefore, football spread faster in British ruled regions of the continent (Pannenborg 2012: 26). See Martin (2002) [1995] as one historical account of the rise and role of football in French colonial Africa. 
collective political mobilization. It was frequently a rejection of colonial and repressive structures that led to the self-organization of matches, leagues, and the first clubs. Football thus became a field of conflict between African nationalists and colonial administrators and a significant arena of the struggle against colonialism and Apartheid (Wachter 2006: 285; Alegi 2010: 50-3; Korr and Close 2008). Taking the ambiguity of football in colonial Africa into consideration, to portray the game as a battlefield of colonial rule versus African resistance sheds light on an important feature of the role of football. However, in daily life, football went beyond a clear-cut dichotomy between locals and colonials. Over time and across the continent it was a multifarious field of various interests of the different actors involved. Beyond that, football may have been a daily practice of sheer enjoyment and sporting ambitions of Africans and colonials alike (Martin 1995 [2002]: 99-126; Alegi 2010).

From the 196os onwards football became an engine of political endeavors to create national unity in the continent's many young and ethnically heterogeneous states (Armstrong and Giulianotti 2004; Alegi 2010: 54-77). The governing African elites also used football as a means of promoting the new African man. In particular the Ghanaian president, Kwame Nkrumah, evoked the image of a man of integrity, a man sincerely devoted to serving his nation, as the prototype of the new and authentic African man. Football in general, and the Ghanaian national team in particular, were seen as a way of expressing this philosophy (Wachter 2006: 288-91). In many African countries, government support helped to make football a vehicle of emancipation from colonial values, and, according to Wachter (2006: 291), the emphasis laid on intelligence and technique on the football field created an explicit counter-model to the colonial idea of a natural, powerful, but unsophisticated African style.

\section{Images and Manifestations of the Other in Football}

In African contexts as well as in other parts of the world, the development of national playing styles was explicitly desired as a means of cultural selfaffirmation and as a distinguishing feature. Today, unique playing styles are still ascribed to many national teams (Eisenberg et al. 2004: 152; Lanfranchi and Taylor 2001: 191-211). ${ }^{5}$ How successful was the struggle to overcome colonial ascriptions in the African context? It seems that both the emphasis on technique

\footnotetext{
5) For instance, while African national teams are widely considered as playful, South American teams are labeled as elegant and European teams as result-oriented (see Parr 2003, Eisenberg et al. 2004; Archetti 2006).
} 
as a counter-model to colonial values as well as the colonial image of Africans as playful, wild, and unsophisticated have contributed to the current notion of African football as trick-loving, powerful, and immature. In this respect, the African footballer would fit into the category of what Ben Carrington (2010) has named “'the black athlete", which builds upon an alleged entity of black sportsmen and thus constitutes an exception to the white rules of sports.

Across all borders and regardless of how individual national teams perform, reports on football in Africa regularly romanticize it as childish and unspoilt, qualities which distinguish it from professional European football (Thielke 2009: 34; Bale 2004: 244-5). Especially coaches and football officials use this explanatory model (see King 2004: 20). Thus, the director of a football academy of a European club in Ghana, when talking about an African style of play, said: "African players are natural born sportsmen. They have a nice, good style" (Interview 1). When the German coach Dietmar Demuth speaks of the "suppleness" of the Africans who exhibit "so much playfulness and so much pleasure in the game," or when Uganda's former national coach, Csaba Lázsló from Romania, refers to Africa as a "gold mine" of "love of the ball, elegance and passion for playing" (Thielke 2009: 122 and 44), they are representative of many European coaches in Africa who admire the supposedly natural African talent for football, but who, according to widespread claims, frequently had to first teach the players discipline in order to attain success (Thielke 2009: 181; Konrad and Joswig 2011; cf. Parr 2003: 55; Fanizadeh and Pinter 2005: 264).

Just as these notions are not restricted to individual national teams but extended to alleged cultural entities ("Africa") (Müller 2009: 278-9), the same images are also applied to football migrants from Africa, South America, or southern Europe. These culturalist ascriptions often serve as an explanation for particular actions of immigrant footballers on the pitch. For instance, Zinedine Zidane's legendary head butt in the World Cup Final in 2006 was prominently interpreted in the media as a culturally normed response to defamatory comments, and this response was variously described as being due to Zidane's Muslim, Arab, or Mediterranean roots (Bierschenk 2013: 77-80). ${ }^{6}$ Correspondingly, in German football hard tackles or fouls by southern players (no matter whether southern European, African, or South American) are explained as a result of their innate hot-bloodedness (Zifonun 2008). Even players themselves may explain certain behavior on the pitch with cultural peculiarities. Charles Akonnor, a former Bundesliga professional between 1992 and 2005 and a

6) Following a verbal confrontation, Zidane, the son of Algerian immigrants and captain of the French team, head butted his Italian opponent Marco Materazzi in the chest. 
member of Ghana's national team recalls the historic defeat against Germany in 1993: After halftime, when Ghana still led by one goal to nil, he remembers that it felt as if "we became drunk. That's [...] African style. [...] Then, [the German] team came and scored six goals. [That's] African mentality. Maybe we thought, 'it is over so let's celebrate'" (Interview 2).

Where do these images come from and why are they so powerful? In the context of African footballers, the concept of "the black athlete" reflects the widespread belief in such ascriptions. "The black athlete," the manifestation of the white (sports)man's other, "forged from a combination of preexisting, centuryold racial folklores, religious fables and the scientific tales of nineteenthcentury racial science" (Carrington 2010:1). In this, the above outlined colonial and post-colonial ascriptions of African football, the development of playing styles and the concept of an African (sporting) body, perpetuated this manifestation. The contemporary power of such concepts and stereotypes grounds in the continuous circulation of its images, particularly "by the "sports media, (...) by the advertising industries, by pseudo-scientific inquiries and the educational system and by athletes themselves, fans, sport administrators and officials" (Carrington 2010: 2). Thus, the popular image of the powerful or trickloving African sportsman as a characteristic of "the black athlete" has become an inherent part of the social knowledge about Africa over time.

This explains already the power of those ethnic ascriptions in sports to a large extent. However, this social knowledge has to guarantee predictability and has to be verified continuously (Müller and Zifonun 2010: 13-4; Zifonun 2008: 164). In the context of football, ethnic ascriptions create an expectation on the part of the observer that players will behave differently on the pitch depending on where they come from (Müller 2010: 407-9). For instance, if a Malawian player makes a tactical mistake on the pitch, or if a Cameroonian out-dribbles two opponents within a small space, these actions will often be interpreted with reference to existing ethnic knowledge which ascribes to these players an unsophisticated and immature style of play or, accordingly, an enjoyment of the game. Thereby, certain actions of African footballers on the pitch are explained by referring to this stock of social knowledge of alleged African attributes. When these ethnic ascriptions then seem to be continuously verified, the social knowledge reproduces itself and adds to the power of such ascriptions.

Manifested culturalist ascriptions in the context of African football migration thus go back to historical constructions of otherness. Actual processes of this construction can be located in the history of African football migration to Germany, which will be described in the following section. 


\section{African Professional Football in Germany and Racism in Stadiums}

African football players are a comparatively recent phenomenon in German football. ${ }^{7}$ Due to colonial rule in Africa, African footballers had played for decades in the professional leagues of other European countries, such as France, Belgium, or Portugal (Taylor 2006: 17-20). In Germany there were only a few African footballers, starting in the 196os. The Ghanaian Charles Gyamfi was the first player to come to Germany from an African club. He joined Fortuna Düsseldorf in 1960 for one season after the club had offered him a contract following a series of friendly matches in Ghana (Tödt and Scheve 2011). After the introduction of the German Bundesliga in 1963, a decade passed before the next player from Africa came to Germany. Ibrahim Sunday left Ghana to join Werder Bremen after being Africa's Footballer of the Year in 1975; however, he was unable to gain acceptance. Looking back, he says: "My new team mates didn't say much to me, just hello and goodbye. For weeks on end, just hello and goodbye. (...) I would have liked to talk to them. But no one in the team could speak English. The people at Werder weren't unkind, but they didn't know how to behave with me. I was dragged along from one training session to the next, for two years. I was the man for the substitutes' bench or the stand, and that was often the right place for me. I couldn't show my skills" (Ewers 2010: 125-6). Sunday ended his professional career in 1977, after two years and a total of 45 minutes play. It was not until the late 1980 s that a few African players again joined Bundesliga clubs. Etepe Kakoko, from what was then Zaire, played for VFB Stuttgart and 1.FC Saarbrücken, but was unable to attract sustained attention. But Anthony Baffoe from Ghana and Souleyman Sané from Senegal, who grew up in Germany and France respectively, as well as the Ghanaian Anthony Yeboah were well-known players for many years. From the beginning of the 1990s, other Africans played successfully in the Bundesliga: Jay-Jay Okocha, Samuel Kuffour, and Jonathan Akpoborie. On the one hand they were crowd

\footnotetext{
7) This account of the history and situation of African footballers in Germany is restricted to the context of the Federal Republic before and after reunification. In East Germany's Oberliga (the highest league in the GDR), no foreigners were allowed due to the policy of promoting national football and the practice of exclusion in the GDR's high-performance sports system. Thus, for example, the Guinean Souleymane Chérif, who came to the GDR in 1961 under a training agreement to do an apprenticeship and then a degree course in engineering, and who played in his spare time for the second division club SC Neubrandenburg, was refused the right to play in the top division after his club moved up in 1964. After completing his training, Chérif left the GDR and played from then on in his home country. He was chosen for the national team and in 1972 he was elected Africa's Footballer of the Year (Jahn 2010).
} 
favorites and advertisements for their clubs, but on the other they were often subjected to racist insults, especially in the stadiums. While the media often exoticized their style of play as graceful, childish, and playful, an expression of both admiration and condescension, fans of the opposing teams regularly threw bananas and shouted racist insults (Ehlers 2009).

In 1990, Sané, Baffoe, and Yeboah reacted to the continual attacks, describing their situation in Germany in an open letter addressed to German football fans: "In no other country in Europe are black footballers exposed to such insults" (Theweleit 2007). In the late 1980 s and early 1990s, racism, especially against black Africans, was a widespread phenomenon in German professional football. Every week it was common to hear fans shouting insults or producing imitations of monkey sounds. Harald Schumacher, a former national goalkeeper for Germany, commented: “That isn't racism', it's 'normal for players in the opposing team.' And in answer to the question why German players are not insulted in this way: 'Maybe because they don't look like monkeys'” (Tatort Stadion 2001).

Attempts were made by the German Football Association and by fan initiatives to counter the growing racist tendencies in the stadiums at this time; in a campaign organized in 1992, for instance, all Bundesliga teams turned out on a particular match day in jerseys which said "My friend is a foreigner" [German Original: "Mein Freund ist Ausländer"]. Whereas this campaign was both a reaction towards football-related racism and fatal attacks against asylum seekers and immigrants in various German cities at that time, its message had an ambiguous connotation since it implied a natural division between natives and foreigners, and referred to black German citizens, for instance, as being foreigners. However, besides such symbolic political gestures (and a possible increasing awareness against openly articulated racism and xenophobia in Germany in general), a harsher system of penalties for racist incidents (such as losing points or closed-door matches), and long-term fan projects have proved to be effective (Behn and Schwenzer 2006: 347).

Today's fan culture in German professional football differs from the situation of the early 1990s. On the one hand, although fan culture has never been homogeneous, it has further differentiated since then. There is now a greater variety of football- and event-oriented supporting groups who co-exist (e.g. "Ultras," "Supporters," "Hooligans"). On the other hand, the increasing professionalization of football has led to an increased consumer-oriented fan culture (Pilz 2012; see Giulianotti 2002 for a detailed differentiation of fan identities). Official measures against racist tendencies and the differentiation of fan groups have contributed to less openly expressed racism in stadiums since the mid1990 (Pilz 2009 and 2012). 
These developments reflect the subjective impression of some African footballers in Germany, such as Souleyman Sané and Gerald Asamoah (Am Ball Bleiben 2007; Bock 2011). Asamoah, however, reports that he was a victim of racist insults even during the 2000 s and particularly just a few months after he took part in Germany's successful World Cup appearance in 2006 (Asamoah 2013: e.g. 72 and 146). Racism, therefore, has not disappeared from German stadiums. However, racist insults and attacks have largely shifted from the professional to the amateur sphere, even though racist tendencies can still be observed in all fan scenes, including the Bundesliga (Pilz 2009 and 2012; Völker 2009; Glindmeier and Todt 2006). Moreover the articulation of racism seems to have shifted from inside the stadiums to periods before and after matches (e.g. when fans use public transport to travel), and openly articulated insults have given way to more subtle forms of discrimination. For instance, in the event of sportive failure, fans are harsher towards African players than they are towards their German teammates. In these commentaries, footballers of African origin become "de-individualized" and are not referred to as individual players but as Africans. Failure on the pitch, it seems from this perspective, often lies in their African roots (Pilz et al. 2006: 344-5).

\section{African Football Migration Today: Appreciation, Discrimination, and Self-charismatization}

Today, African footballers seem to be increasingly appreciated by German clubs (Theweleit 2009). An important factor in this development was the Bosman ruling issued by the European Court of Justice in 1995. Among other things this ruling extended the existing right to freedom of movement for workers within the European Union to include professional football. The regulation restricting the number of foreigners per team to three was abolished at first in favor of players from the European Union, and has since then been further relaxed. In addition, some African players like the Ghanaian international Samuel Kuffour who had played in Germany for several years obtained German citizenship in order to avoid competition among non-EU teammates (Interview 3). Since the 2006/07 season then, any number of non-EU nationals may be employed in German professional football. This means that a team could play a match with 11 Africans in their squad. This has yet to happen, but the number of players from Africa has certainly risen significantly (Dembowski 2010: 34$){ }^{8}$

8) Reliable statistics regarding the number of African players are difficult to access. This is mainly due the problem of defining the specific group of African players. While some databases include 
This process is reflected in the spread of football academies all over Africa. On the international level, some clubs have started up such football academies in order to begin an integration process for foreign talents while they are still in their home countries. Feyenoord Rotterdam, FC Utrecht, and Red Bull Salzburg, for example, run such schools in Ghana (often in cooperation with sponsors) with the aim of training talented young players themselves at a reasonable cost. ${ }^{9}$ Thereby, football academies fuel the dream of thousands of young African talents and, thus, contribute to the current prominence of African football migration to Europe in general. In addition, they also contribute to the representation of African players as being fundamentally different from Europeans and, thereby, carry forward a colonial rhetoric of otherness. As local organizers explain, the young footballers are able to get used to European culture and ways of behaving in the academies. Any African player who wants to succeed in Europe must leave his "African identity" behind at the airport, says the director of a football academy. In other words, integration is achieved through re-education, with reference to what is assumed to be an African attitude and African style of play, both of which need to be changed to some extent if an African player wants to be successful in Europe (Interview 4). This view seems to be widespread: for instance Rudi Gutendorf and Berti Vogts, German coaches who have both worked in Africa, believe that if African players were less in love with the ball and had a bit more understanding of modern tactics, African national teams could be on a level with Brazil or European teams (Thielke 2009: 35 and 181).

It is a remarkable fact that African players in Germany also see the lack of "discipline," "tactical understanding," and elaborate ball skills in Africa as the main difference between African and German football. When an experienced footballer from West Africa, looking back on his professional career in Germany between 2000 and 2010, says, "I've learned a lot here, tactics, discipline," while in Africa it is the fun of the game that is important, he is representative of a whole generation of African footballers in Germany (Interview 5). His views are endorsed by young talents in Africa who are dreaming of a career in Europe. For example, in answer to the question of what a young player like himself needs in order to become a professional in Europe, a current academy

players who are citizens of an African country, others exclude footballers of African origin who, regardless of their actual citizenship, were brought up outside Africa. Indeed, neither citizenship nor socialization is an appropriate category when analyzing the construction of otherness. More important is the self- and social perception of players as African.

9) German clubs do not run their own academies in Africa. The lack of expertise and expected high costs are mentioned by some managers as reasons for the absence of German clubs (Biermann 2008). 
player in Ghana said: "As an African footballer (...) the key is discipline. If you don't have the discipline and even if you are the best player here, you are not going to play" (Interview 6). Gerald Asamoah, who left Ghana and moved to Germany with his parents at the age of 12, shares this view: African players, he confirms, "lack discipline, systematic order and seriousness. I myself have learned this not before being in Germany" (Fritsch 2013). While such statements stress a perceived difference between European and African football, players also emphasize an ability to learn ascribed European skills on their part. According to them, this ability is needed in order to succeed in European football.

Nevertheless, it is important to African players that they should be perceived as African, or that they should not completely give up their mentality. Thus, Andrew Sinkala, a former Zambian international, who played in the Bundesliga for many years between the late gos and 2012, says: "When you come here [to Germany] (...) you lose a bit of your culture. But (...) you will always play your football, and for instance when you get the ball (...) you will dance with the ball a bit. (...) The fans (...) see, 'Ok, he has to do what he did in Africa', but that is not German football and that is not the mentality of the Germans. (...) When Jay-Jay Okocha goes home [to Nigeria] for an international match, he says to himself, 'When I'm at home, I always play my football' and he performs his tricks. Maybe he has also used these tricks in Germany, but not as much [as] when he was at home in the national team" (Interview 7).

That the difference expressed by European coaches, officials, and journalists on the one hand and by African players on the other hand refers to the different styles of play, can possibly be traced back to the above mentioned specific historical developments which have given rise to different stocks of social knowledge about football. However, the references to diverging cultural conceptions and practices also imply that there is a biological explanation. Particularly, representations of black German and African players who have learned to play football as children in Germany underline this.

The prominent case of the Boateng brothers may serve as an example. Jérôme (a German international) and Kevin-Prince Boateng (who was capped for various German junior national teams before he became a Ghanaian international in 2010), German born half-brothers with a Ghanaian father are continuously constructed as being the personal opposite of each other in the media. While Jérôme, who was raised in a bourgeois quarter in Berlin, is known for his cool-minded attitude and discipline, Kevin-Prince grew up in one of Berlin's rough neighborhoods and is frequently portrayed as the bad guy, an undisciplined ghetto-kid. Both have become recognized players in recent years 
and both share, according to media reports, an African elegance that contributes to their outstanding football talent. But while Jérôme apparently made it to become a member of the German national team since he could combine his talent with discipline, Kevin-Prince got excluded from a likely career as a German international as a result of his ongoing undisciplined behavior on and off the pitch. Thus, according to media reports and statements from German football functionaries, Jérôme fits as a German international because he was able to learn and add German skills to his style of play whereas Kevin-Prince was not (see Grossekathöfer 2010). Their case underlines both the prominent notion of a natural African talent as well as the need to combine alleged African skills with an ability to adapt to an ostensibly more sophisticated style of play and behavior off the pitch in order to become a star player in German football. However, the popular image of the good guy versus the ghetto-kid is subject to change. Recently, on the one hand, Kevin-Prince became a figurehead against racism in the media and even for the UN when he left the pitch during a friendly match in Italy as he was continuously offended by racist insults of fans of the opponent team. However, although his reaction was widely appreciated, it was explained by his hot-tempered character and pride, formed both by his socialization and African origin. Jérôme, on the other hand, faced severe criticism in the media for a hard tackle against a teammate during his team's training session. According to him, the critique intended to construct a connection to Kevin-Prince's bad image and thus explained his tackle as rampant savagery that must have its roots in the family. "In the end", Jérôme concludes, "it all goes back to skin color," which implies that alleged African attributes like untamed and undisciplined behavior seem to be natural qualities of black players that (despite a socialization in a bourgeois environment in Germany) are difficult to discard (Rosentritt 2013).

Though the notion of natural African features goes beyond such media representations, remarkably, self-representations of black German players like the one of a current striker of a German third division club, who came to Germany at the age of six, underline this notion: "I think you can tell that someone is an African footballer. I can't really say why, but I think there is a difference in the way Africans and Europeans handle the ball. But I think that's OK. Even Africans like me who have grown up here have some special characteristics. It's something that can't be denied, no matter whether you learned to play in Africa or here in Europe" (Interview 8). Even though the 33-year-old was taught "everything he knows about football" in the junior teams of a Bundesliga club, he describes himself and his way of playing football as "African," which, in view of the fact that his socialization in football took place in Germany, can only 
be ascribed to natural talent and not to acquired skills. In this context, Müller (2009: 278-9) underlines skin color as a distinctive feature. In the world of football, players with a dark skin, regardless of their place of origin or place of socialization, are generally believed to have a better technique than footballers with a light skin. Thus, supposed differences in ball skills between players of different skin color are explained by their genetic constitution and not, for instance, by specific training (see McCarthy et al. 2003).

As shown above, the idea of different football styles is shared by players from Africa. On the one hand they express an intention to learn discipline and a wish not to give up a perceived African mentality, but on the other hand they think there is a natural difference between African and European football, suggesting an apparently biological explanation for any differences in the way football is played (see Müller 2009: 278-9). Zifonun (2008) has observed similar self-ascriptions and other-ascriptions on the amateur level in respect of Turkish immigrant clubs in Germany. The members of a Turkish football club in Mannheim are not only described as hot-tempered by players, officials, and supporters of other (mainly German) teams, but this is also how they have come to see themselves, for they explain their behavior as being due to their natural Turkish hot-bloodedness. Thus, there is "a shared knowledge of ethnic differences" (Zifonun 2008: 166). As this difference is formulated as being natural, neither the hot-temperedness of the Turkish players, nor the suppleness or lack of discipline of the Africans needs to be explained (see Zifonun 2008: 166). Moreover, Zifonun (2008: 172-3) argues that since this shared knowledge apparently serves to maintain self-images and images of the other and thus fixes ethnic boundaries between autochthonous population and immigrants it "simplifies communicative understanding (...): the use of a stereotype that describes the "nature' of a person (...) is (supposedly) not insulting."

Although ascriptions of suppleness or trick-loving may imply admiration of certain technical skills, they are nevertheless denigrating towards African players, suggesting they naturally lack other important skills which need to be learned if they want to succeed in the competitive world of sport in Europe. Locating the African player in this way on a lower level of development is the result of an evolutionary worldview. On the other hand, African players use the idea of a distinct African style as ethnic self-charismatization. Here, selfcharismatization refers to an (implicit or explicit) investment in ethnic capital (Soeffner 1997: 65-7 and 81-2; see Müller and Zifonun 2010: 26-7). Powerful ethnic and cultural ascriptions which may simultaneously imply facets of degradation (e.g. tactical immaturity) and admiration (trick-loving style) overshadow other possible interpretations of certain behavior on the field. By repeatedly 
confirming those ascriptions on the pitch African players acknowledge and ritualize such stereotypes. The individual footballers become depersonalized and simply portrayed as black or African players who allegedly share common cultural and biological features (see Pilz et al. 2006: 344-5). Thus, African players do not communicate an image of an African style of play. Rather, they seem to incorporate it and thus become the embodiment of ethnic ascriptions. Since an alleged African style of play entails admiration, ethnic ascriptions may become an asset for an African footballer. For instance, fulfilling ascribed expectations by fans and the media on the pitch as well as showing an ability to learn alleged European skills may contribute to a unique feature and reconfirm the individual. This process of self-charismatization of an African player as African may promise sporting success and contribute to a distinguished position as a celebrated star and as an advertisement for a club as in the cases of Gerald Asamoah and Hans Sarpei.

Other African players like Charles Akonnor support this view: "If an African player has an African style and adds some European skills, then he will be a star" (Interview 2). Anthony Baffoe, who is now an adviser to the Ghanaian Football Association, adds that if an African player wants to become a star he would need to pay more attention today to "the essential things (...) without losing his elegance and his spontaneity" (Interview 9). Referring to this, Andrew Sinkala recalls his first training session with Bayern München's squad after he was transferred from the Zambian side Nchanga Rangers FC in 1999. "My coach [Ottmar] Hitzfeld [observed me for some time and said], 'Come on, I will be honest with you: good boy, good technical skills. The things you do are good. But in two weeks all the players will know your tricks because they know that Andrew [...] will keep the ball for some time and dance with the ball. So you will always lose the ball. [...] You have to learn how the Germans play the ball. Then you combine it with your skills and it will work out"' (Interview 7).

Sinkala's recall of Ottmar Hitzfeld's claim reflects in particular those European coaches and functionaries who run football schools in Africa. They also consider that an important part of the training of young African talents is to see that they preserve their individual African style of play, while at the same time adapting to European virtues. "Here [in Ghana], the biggest cheer is when someone puts the ball through someone else's legs. And that's football culture here," is how the head of the talent scouting department of an academy in Ghana describes the pure enjoyment of the game shown by African footballers, which should not be dampened during their training at the academy. "For an African coming to Europe they can't change (...) their culture. (...) They have to adapt to the European mentality (...) but (...) on a middle level" (Interview 10). 
The director of another academy in Ghana confirms this view when defining the goal of his school: "[A player trained by us] should be as competitive as possible. He should simply combine so many things that one otherwise sees only in an African [or] only in a European, and which one always wishes it could be possible to have in one player. And of course that is the hope from a sporting point of view" (Interview 4, emphasis by the author).

Self-styling as an African player can thus be explained by higher hopes of success. These hopes of success are linked to the expectations of the German clubs, coaches, and fans; in other words, self-styling as an African player promises sporting and economic success, because it is expected that African players incorporate alleged African football abilities which distinguish them successfully from other players. In this respect, the need to "play the white man" in order to gain recognition in European football (King 2004: 20) may refer to an alleged lack of discipline, tactical understanding, and result-orientation among African footballers that they supposedly need to overcome. However, in terms of technical skills and elegant playing styles, African players would rather have to play the black man to get appreciated by teammates, fans, coaches, and the media.

This process can be conceptualized as a form of self-charismatization (Soeffner 1997: 65-7 and 81-2). Self-charismatization goes beyond other possible conceptualizations of ethnic capital or strategic essentialism. Whereas ethnic capital would imply a rather passive asset of skills, Spivac's (1987) concept of strategic essentialism would refer to a collective self-empowerment of a marginalized group of people who consciously decide to fulfill overgeneralized ascriptions as social action in order gain advantages. Both are not the case among African football migrants. Firstly, the outlined accounts show that the self-styling as an African player is not a passive quality but a continuous process of fulfilling the expectations of fans, functionaries, and the media. In addition, although players may be overgeneralized as simply Africans, which may refer to the ascription of shared ethnic capital to a certain extent, reactions towards this overgeneralization are individual actions on the pitch. However, it is important to note that the individual self-styling is widely shared among African players and thus reflects the alleged authentic and "permanently possible presentness of the extraordinary" (Soeffner 1997: 81-2) such as the exotic African style of play in order to fulfill ascribed expectations collectively. Furthermore, however, it is questionable whether the self-styling as an African player is a strategic act. Since the notion of African football skills as explicit natural qualities is widely shared among African players themselves it rather reflects an implicit and embodied reaction towards shared notions of what it 
means to be African in football. This process of self-styling can thus be conceptualized as a form of self-charismatization since it is individual actions that may lead to individual advantages and which (since it is shared collectively) manifests the power of the discourse of the African other. Finally, it implies a personal charge with meaning which promises social recognition; a meaning, however, that may exaggerate and is carried away from the actual abilities of a player and thus lead to his charismatization.

African players serve and share the stereotype of a specific African mentality in order to meet German expectations, and thus to be accepted. What is important here is not whether a player is really in love with the ball or not, but that he shares this knowledge and is able to describe match situations, which could be interpreted differently, in the same way as fans, coaches, and players in Germany, by referring to a natural African playing style. This knowledge is thus not only shared, but also actively contributed to by African players. In the early post-colonial phase African national teams tried to create styles that were distinct from that of the colonial authorities, and the idea of the playful, trick-loving, elegant, or powerful African can be traced back to these styles. It is reproduced by African players today when they deliberately present themselves in this way, as in the case of Andrew Sinkala who likes to entertain the spectators by dancing with the ball (Interview 7). ${ }^{10}$

Although (usually) no openly racist insults are intended when German players, coaches, and fans articulate this shared knowledge, the stereotype of a natural African mentality is nevertheless problematic. It places African and German football players on naturally different levels, where the German players are tactically more mature and more professional, even if more technically limited. Although the knowledge of a naturally African style of play is shared and may promise sporting success, African players - despite expressed admiration for their technical skills - are still perceived as being on a lower developmental level.

\footnotetext{
10) Noticeably, not every African player may present himself like his. However, even then, African players often refer to African attributes of a specific inherited style. For instance, Gerald Asamoah begins his autobiography with an explanation of why he does not fit into the category of a playful and technically skilled African player. Rather, he portrays himself as a player with a fighting spirit and explains this in terms of his ethnic identity as an Ashanti who, in his words, are known for this particular fighting spirit (2013: 11-3). Likewise, if African footballers do not fit into the category of a playful, trick-loving player (e.g. defenders who may play physically), media reports often stress other alleged African attributes and nourish yet another colonial stereotype, of powerfulness for instance (see Theweleit 2009).
} 


\section{Conclusion}

What does the othering and self-charismatization of African players tell us about the representation of recognized and celebrated African migrants and black Germans in football and beyond? First of all, processes of othering, it seems, are elementally embedded in football (see Burdsey 2011), be it to differentiate one's team from the opponent, as a means of self-affirmation as fan or by referring to an existing stock of social knowledge of migrant footballers in order to explain certain actions on the field. Therefore, the construction of an other like an African player may follow from a "cultural logic of the football stadium" (Schwenzer and Selmer 2010: 387; Behn and Schwenzer 2006: 353). Indeed, subtle forms of discrimination like the construction of otherness in professional sport are widespread phenomena as the prominent image of hyper-virility and savagery of Polynesian rugby players in New Zealand indicates (Besnier and Brownell 2012).

However, the stereotype of a naive African style of play, characterized by playfulness and tactical immaturity, is based not least on an evolutionary worldview and has become established in the social knowledge of the football milieu. Playing styles largely refer to colonial ascriptions and postcolonial counter models of what was (and is) perceived to be genuinely African. By implicitly referring to a colonial worldview, even the acceptance and appreciation of successful players is influenced by a general image of the continent that implies backwardness. In this respect, the cheering of a star player as an expression for the joy over alleged African characteristics as well as forms of open racism in the stadium are often only two extremes of a continuum in respect of African football migrants: the manifestation of the apparent otherness.

Self-charismatization among African migrant and black German players contributes to this manifestation. By acknowledging alleged African attributes it seems to contribute to an affirmative African identity and serves the social inclusion of migrants at first sight. However, because it (implicitly) acknowledges the stock of widespread social knowledge in Germany which misinterprets an African style of play as an expression of natural qualities rather than as a dynamic historical construct, it reflects a problematic colonial rhetoric (see Bale 2004: 242). Thus, self-charismatization may contribute to an acceptance among fans and teammates; however it sets notions of difference and cultural inferiority.

Thus, although alleged and acknowledged difference may ostensibly work for some African footballers, it reproduces the notion of an African other that 
may go beyond the social field of football. If the representation of recognized and even celebrated African migrants and black Germans like professional footballers continues to ground in alleged physical and incorporated features, colonial rhetoric and racist-oriented worldviews have a prominent stage (e.g. through mass media coverage of football) that may set the image and discourses of what Africa is in general.

\section{List of interviews}

Interview 1: Director of a professional football academy in Ghana (anonymous), March 10, 2010 Interview 2: Charles Akonnor, March 11, 2010, Accra, Ghana

Interview 3: Samuel Kuffour, April 19, 2010, Accra, Ghana

Interview 4: Executive Director of a professional football academy in Ghana (anonymous), March 3, 2010

Interview 5: Former professional and current amateur player in Germany from West Africa (anonymous), April 8, 2011

Interview 6: Junior player of a football academy in Ghana (anonymous), April 27, 2010 Interview 7: Andrew Sinkala, September 29, 2011, Augsburg, Germany

Interview 8: Current professional player from West Africa (anonymous), March 25, 2011 Interview 9: Anthony Baffoe, February 27, 2010, Cape Coast, Ghana

Interview 10: Head of Scouting of a professional football academy in Ghana (anonymous), April 27, 2010

\section{References}

Alegi, Peter 2002. Playing to the Gallery: Sport, Cultural Performance, and Social Identity in South Africa, 1920s-1945. The International Journal of African Historical Studies, 35 (1): 17-38.

2010. African Soccerscapes. How a Continent Changed a World's Game. Athens: Ohio University Press.

Am Ball bleiben 2007. Rassismus im Ligaalltag. Am Ball bleiben, 2007. Accessed March 14, 2012. http://www.amballbleiben.org/html/themenfelder/rassismus-02.html

Archetti, Eduardo P. 2006. Fußball und Nation in Argentinien: „Kreolischer“ Stil und der "goldene Junge" Maradona. In: Eva Kreisky and Georg Spitaler (eds.) Arena der Männlichkeit. Über das Verhältnis von Fußball und Geschlecht. Frankfurt/Main and New York: Campus: 314-27.

Armstrong, Gary and Giulianotti, Richard 2004. Drama, Fields and Metaphors: An Introduction to Football in Africa. In: Gary Armstrong and Richard Giulianotti (eds.) Football in Africa. Conflict, Conciliation and Community. New York: Palgrave MacMillan: 1-24.

Asamoah, Gerald (with Großmann, Peter) 2013. „Dieser Weg wird kein leichter sein ... “Mein Leben und ich. München: Herbig.

Bale, John 2004. Three Geographies of African Footballer Migration: Patterns, Problems and Postcoloniality. In: Gary Armstrong and Richard Giulianotti (eds.) Football in Africa. Conflict, Conciliation and Community. New York: Palgrave MacMillan: 229-46. 
Baller, Susann and Cornelissen, Scarlett 2011. Prologue: sport and the city in Africa. The International Journal of the History of Sport 28(15): 2085-2097.

Bardow, Dominik 2013. Vom Fußballer zum Netz-Junkie. Hans Sarpei hat sich zur Internet-Marke gemacht. Der Tagesspiegel, May 16, 2013. Accessed September 30, 2013. http://www.tagesspiegel.de/medien/vom-fussballer-zum-netz-junkie-hans-sarpei-hat-sich-zur-internet-markegemacht/8219040.html

Behn, Sabine and Schwenzer, Victoria 2006. Rassismus, Fremdenfeindlichkeit und Rechtsextremismus im Zuschauerverhalten und Entwicklung von Gegenstrategien. In: Gunter A. Pilz, Sabine Behn, Andreas Klose, Victoria Schwenzer, Werner Steffan and Franciska Wölki (eds.) Wandlungen des Zuschauerverhaltens im Profifußball. Schorndorf: Hofmann: 320-435.

Besnier, Niko and Brownell, Susan 2012. Sport, Modernity, and the Body. Annual Review of Anthropology 41: 443-459.

Biermann, Christoph 2008. Africa-Cup: Weltklasse - und die Bundesliga schaut weg. Spiegel Online, February 7, 2008. Accessed September 26, 2013. http://www.spiegel.de/sport/fussball/ afrika-cup-weltklasse-und-die-bundesliga-schaut-weg-a-533086.html

Bierschenk, Thomas 2013. Zidanes Kopfstoß: Kampf des roten Felsenhahns oder Männerfreundschaft? Plädoyer für eine feldforschungsbasierte Ethnologie. In: Thomas Bierschenk, Matthias Krings and Carola Lentz (eds.) Ethnologie im 21. Jahrhundert. Berlin: Reimer: 77-96.

Bock, Andreas 2011. “... und dann seid Ihr stumm”. Souleyman Sané über Rassismus. 11 Freunde, November 23, 2011. Accessed March 14, 2012. http://alt.11freunde.de/geschichtsstunde/106898

Burdsey, Daniel 2011. They Think It's All Over ... It Isn't Yet! The Persistence of Structural Racism and Racialised Exclusion in Twenty-First Century Football. In: Daniel Burdsey (ed.) Race, Ethnicity and Football. Persisting Debates and Emergent Issues. New York and London: Routledge: $3^{-18 .}$

Carrington, Ben 2010. Race, Sport and Politics: The Sporting Black Diaspora. London: Sage.

Couzens, Tim 1982. "Moralizing Leisure Time": The Transatlantic Connection and Black Johannesburg, 1918-1936. In: Shula Marks and Richard Rathbone (eds.) Industrialization and Social Change in South Africa: African Class, Culture and Consciousness, 1870-1930. London: Longman: 314-337.

Darby, Paul 2010. "Go Outside": The History, Economics and Geography of Ghanaian Football Labour Migration. African Historical Review 42 (1): 19-41.

Dembowski, Gerd 2010. Ballarbeit. Szenen aus Fußball und Migration im Profifußball. In: Diethelm Blecking and Gerd Dembowski (eds.) Der Ball ist bunt. Fußball, Migration und die Vielfalt der Identitäten in Deutschland. Frankfurt/Main: Brandes \& Aspel: 31-7.

Ehlers, Mathias 2009. „Kicker“: Knietiefim Kolonialismus. „Langbeiniger Senegaltänzer“. 11 Freunde, December 4, 2009. Accessed March 14, 2012. http://alt.11freunde.de/geschichtsstunde/126178/ langbeinige_senegaltaenzer

Eisenberg, Christiane, Lanfranchi, Pierre, Mason, Tony and Wahl, Alfred (eds.) 2004. 100 Years of Football. The FIFA Centennial Book. London: Weidenfeld \& Nicolson.

Ewers, Christian 2010. Ich werde rennen wie ein Schwarzer, um zu leben wie ein Weißer. Die Tragödie des afrikanischen Fußballs. Gütersloh: Gütersloher Verlagshaus.

Fair, Laura 1997. Kickin' It: Leisure, Politics and Football in Colonial Zanzibar, 190os-1950s. Africa 67 (2): 224-251.

Fanizadeh, Michael and Pinter, Markus 2005. Rassismus und Antirassismus im goldenen Zeitalter des Fußballs. In: Michael Fanizadeh, Gerald Hödl and Wolfram Manzenreiter (eds.) Global Players - Kultur, Ökonomie und Politik des Fußballs. Frankfurt/Main: Bandes \& Aspel: 257-74. 
Fritsch, Oliver 2013. Nicht alle Rassisten werfen Bananen. Zeit Online, January 21, 2013. Accessed September 30, 2013. http://www.zeit.de/sport/2013-01/gerald-asamoah-rassismus-ballack

Giulianotti, Richard 2002. Supporters, Followers, Fans, and Flaneurs. A Taxonomy of Spectator Identities in Football. Journal of Sport and Social Issues 26 (1): 25-46.

Glindmeier, Mike and Todt, Jens 2006. Ein ganz normaler Samstag. Der Spiegel, April 2, 2006. Accessed September 26, 2013. http://www.spiegel.de/sport/fussball/rassismus-ein-ganz-normaler -samstag-a-409048.html

Grossekathöfer, Maik 2010. Das Familienduell. Der Spiegel, April 12, 2010. Accessed November 2, 2013. http://www.spiegel.de/spiegel/a-688708.html

Jahn, Michael 2010. Fast wie er wollte. Berliner Zeitung, June 10, 2010. Accessed March 14, 2012. http:// www.berliner-zeitung.de/archiv/der-stuermer-souleymane-ch-rif-waere-beinahe-der-erste-afrikaner-in-der-ddr-fussball-oberliga-geworden---aber-er-durfte-nur-zweitklassig-spielen-fast-wieer-wollte,10810590,10722240.html

King, Colin 2004. Race and Cultural Identity: Playing the Race Game Inside Football. Leisure Studies $23(1): 19-30$.

Konrad, Anja and Joswig, Gareth 2011. Trainer-Globetrotter Jochen Figge über Fußball in Afrika. „Sie bewarfen uns mit brennenden Geckos“. 11 Freunde, October 27, 2011. Accessed March 14, 2012. http://www.11freunde.de/interview/trainer-globetrotter-jochen-figge-ueber -fussball-afrika

Korr, Chuck and Close, Marvin 2008. More than just a game. Soccer vs. Apartheid: the most important soccer story ever told. London: Collins.

Künzler, Daniel and Poli, Raffaele 2012. The African footballer as visual object and figure of success: Didier Drogba and social meaning. Soccer \& Society 13 (2): 207-21.

Lanfranchi, Pierre and Taylor, Matthew 2001. Moving with the Ball. The Migration of Professional Footballers Oxford \& New York: Berg.

Martin, Phyllis 2002 [1995]. Leisure and society in colonial Brazzaville. Cambridge: Cambridge University Press.

McCarthy, David, Jones, Robyn L. and Potrac, Paul 2003. Constructing Images and Interpreting Realities: The Case of the Black Soccer Player on Television. International Review for the Sociology of Sport 38 (2): 217-38.

Müller, Marion 2009. Fußball als Paradoxon der Moderne. Zur Bedeutung ethnischer, nationaler und geschlechtlicher Differenzen im Profifußball. Wiesbaden: VS Verlag.

- 2010. Ethnische und funktionale Differenzierung: Zur Relevanz ethnisch-nationaler Zuschreibungen im Profifußball. In: Marion Müller and Dariuš Zifonun (eds.) Ethnowissen. Soziologische Beiträge zu ethnischer Differenzierung und Migration. Wiesbaden: VS Verlag: 399-421.

Müller, Marion and Zifonun, Dariuš 2010. Wissenssoziologische Perspektiven auf ethnische Differenzierung und Migration. Eine Einführung. In: Marion Müller and Dariuš Zifonun (eds.) Ethnowissen. Soziologische Beiträge zu ethnischer Differenzierung und Migration. Wiesbaden: VS Verlag: 9-33.

Pannenborg, Arnold 2012. Big Men playing football. Money, politics and foul play in the African game. Leiden: African Studies Centre.

Parr, Rolf 2003. Der mit dem Ball tanzt, der mit dem Bein holzt, der mit sich selbst spielt. Nationalstereotype in der Fußball-Berichterstattung. In: Ralf Adelmann, Rolf Parr and Thomas Schwarz (eds.) Querpässe. Beiträge zur Literatur, Kultur-, und Mediengeschichte des Fußballs. Heidelberg: Synchron Publishers: 49-70. 
Pilz, Gunter A. 2009. Rassismus und Fremdenfeindlichkeit im Fußballumfeld - Herausforderungen für die Prävention. In: Stephan Braun, Alexander Geisler and Martin Gerster (eds.) Strategien der extremen Rechten. Hintergründe - Analysen - Antworten. Wiesbaden: VS Verlag: $564-78$.

- 2012. Zuschauergewalt im Fußball - Vorurteile und Diskriminierung: Hooligans, Ultras und Hooltras. In: Bernd Strauß (ed.) Sportzuschauer. Göttingen: Hogrefe: 214-39.

Pilz, Gunter A., Behn, Sabine, Klose, Andreas, Schwenzer, Victoria, Steffan, Werner und Wölki, Franciska 2006. Wandlungen des Zuschauerverhaltens im Profifußball. Schorndorf: Hofmann.

Poli, Raffaele 2006. Migrations and Trade of African Football Players: Historic, Geographical and Cultural Aspects. Afrika Spectrum 41 (3): 393-414.

Rosentritt, Michael 2013. „Am Ende kommt die Hautfarbe ins Spiel“. Der Tagesspiegel, March 25, 2013. Accessed November 2, 2013. http://www.tagesspiegel.de/sport/nationalelf/jeromeboateng-im-interview-am-ende-kommt-die-hautfarbe-ins-spiel/7976186.html

Schwenzer, Victoria and Selmer, Nicole 2010. Fans und Migration. In: Jochen Roose, Mike S. Schäfer and Thomas Schmidt-Lux (eds.) Fans. Soziologische Perspektiven. Wiesbaden: VS Verlag: $387-414$.

Soeffner, Hans-Georg 1997. The Order of Rituals. The Interpretation of Everyday Life. New Brunswick, N.J.: Transaction Publishers.

Spivak, Gayatri C. 1987. In Other Worlds: Essays in Cultural Politics. New York: Methuen.

Tatort Stadion 2001. Ausstellung: Rassismus und Diskriminierung im Fußball. Spieler und Trainer: Kabinengeflüster. Tatort Stadion, 2001. Accessed March 14, 2012. http://www.tatort-stadion.de/ ausstellung/spieler.htm

Taylor, Matthew 2006. Global Players? Football, Migration and Globalization, c. 1930-200o. Historical Social Research 31(1): 7-30.

Theweleit, Daniel 2007. "Wir wollen kein Freiwild sein.” Frankfurter Rundschau, June 1, 2007. Accessed March 14, 2012. http://www.fr-online.de/politik/spezials/-wir-wollen-kein-freiwildsein-///1472610/2750422/-/index.html

2009. Geschätzte Kraftkicker. Afrikaner in der Champions League. Die Tageszeitung, May 5, 2009. Accessed March 14, 2012. http://www.taz.de/1/sport/artikel/1/geschaetzte-kraftkicker/

Thielke, Thilo 2009. Traumfußball. Geschichten aus Afrika. Göttingen: Die Werkstatt.

Tödt, Daniel and Scheve, Jan 2011. Der "Beckenbauer Ghanas" Charles Gyamfi. "Sie riefen mich Kalle". $n$ Freunde, July 17, 2011. Accessed March 14, 2012. http://www.11freunde.de/interview/ der-beckenbauer-ghanas-charles-gyamfi

Völker, Markus 2009. Fremdenfeindlichkeit in Fußballstadien. „Du Bimbo“. Die Tageszeitung, April 23, 2009. Accessed March 14, 2012. http://www.taz.de/!33643/

Wachter, Kurt 2006. Fußball in Afrika: Kolonialismus, Nationsbildung und Männlichkeiten. In: Eva Kreisky and Georg Spitaler (eds.) Arena der Männlichkeit. Über das Verhältnis von Fußball und Geschlecht. Frankfurt/ Main and New York: Campus: 277-95.

Zifonun, Dariuš 2008. Stereotype der Interkulturalität: Zur Ordnung ethnischer Ungleichheit im Fußballmilieu. In: Sighard Neckel and Hans-Georg Soeffner (eds.) Mittendrin im Abseits: Ethnische Gruppenbeziehungen im lokalen Kontext. Wiesbaden: VS Verlag: 163-75. 